\title{
Model Kanal 5G dengan Pengaruh Kelembapan pada Frekuensi 3,3 GHz dan Bandwidth 99 MHz Berbasis Convolutional Codes
}

\section{RENI DYAH WAHYUNINGRUM, KHOIRUN NI'AMAH, SOLICHAH LARASATI}

Institut Teknologi Telkom Purwokerto, Indonesia

Email: reni@ittelkom-pwt.ac.id

Received 10 Mei 2021 | Revised 17 Juni 2021 | Accepted 24 Juni 2021

\begin{abstract}
ABSTRAK
Generasi telekomunikasi kelima (5G) diterapkan pada 2021 dengan frekuensi tinggi yang menyebabkan redaman yang besar dibandingkan pita sub-1 GHz. Penelitian ini mengkaji sistem $5 \mathrm{G}$ dengan frekuensi operasi 3,3 $\mathrm{GHz}$ dan bandwidth $99 \mathrm{MHz}$ berdasarkan spesifikasi $5 G$ dari Cyclic Prefix-Orthogonal Frequency Division Multiplexing (CP-OFDM) numerologi $\mu=1$ menggunakan parameter lingkungan yang diukur secara langsung di kota Bandung. Penelitian ini menemukan bahwa model kanal $5 G$ dengan pengaruh kelembapan maksimum memiliki power delay profile (PDP) 9 path dengan nilai daya yang lebih kecil dan outage performances $(R>C)$ yang lebih buruk dengan gap sebesar 0,3 $d B$ dibandingkan dengan pengaruh kelembapan minimum. Hasil penelitian menunjukkan bahwa penggunaan convolutional codes dapat membantu menghemat Signal to Noise Ratio (SNR) dengan gap sebesar $3 \mathrm{~dB}$. Hasil dari penelitian ini diharapkan dapat memberikan kontribusi bagi perkembangan komunikasi nirkabel $5 G$ di Indonesia.
\end{abstract}

Kata kunci: 5G, model kanal, convolutional codes, PDP, FER, BER.

\section{ABSTRACT}

The fifth generation of telecommunications (5G) implemented in 2021, where high frequency which causes a large attenuation compared to the sub-1 GHz band. This research examines a $5 \mathrm{G}$ system with an operating frequency of $3.3 \mathrm{GHz}$ and a bandwidth of $99 \mathrm{MHz}$ based on the $5 \mathrm{G}$ specification of the Cyclic Prefix - Orthogonal Frequency Division Multiplexing (CP-OFDM) numerology $\mu=1$ using environmental parameters measured directly in Bandung, Indonesia. This research shows that the $5 G$ channel model under maximum humidity has a 9 power delay profile (PDP) with a smaller power value and worse outage performances $(R>C)$ with a gap of $0.3 d B$ compared to the effect of minimum humidity. The results showed that the use of convolutional codes can save the Signal to Noise Ratio (SNR) with gap of 3 $d B$. The results of this research are expected to contribute to the development of $5 G$ wireless communications in Indonesia.

Keywords: 5G, channel model, convolutional codes, PDP, FER, BER. 


\section{PENDAHULUAN}

Perkembangan teknologi telekomunikasi seluler sudah mulai memasuki era 5G. Dengan melihat perkembangan teknologi di setiap generasi, 5G diterapkan pada pertengahan tahun 2021. Teknologi 5G mengalokasikan penggunaan bandwidth yang tinggi pada telepon seluler. Setiap perkembangan teknologi membutuhkan persiapan dalam implementasinya, seperti model kanal. Langkah yang diambil untuk mengambil peluang masuk pada teknologi $5 \mathrm{G}$ harus melihat kembali definisi teknologi $5 \mathrm{G}$ berdasarkan standar yang dikeluarkan oleh ITU-R seperti terlihat pada Gambar 1 Enhanced Mobile Broadband (eMBB) ditujukan untuk skenario yang berpusat pada pengguna untuk mengakses konten multimedia, layanan, dan kecepatan data 20 Gbps. Ultra-Reliable dan Low Latency Communication (URLLC) memiliki persyaratan yang lebih ketat dalam hal kapabilitas seperti throughput, latency, availability dengan Multiple Input and Multiple Output (MIMO), dan millimetre wave communication. Massive Machine Type Communication (MMTC) ditandai dengan banyaknya jumlah perangkat yang terhubung, terutama perangkat yang mengirimkan data yang tidak sensitif terhadap delay. Penelitian ini fokus pada pemecahan masalah enhanced mobile broadband, dimana model kanal memainkan poin terpenting untuk meminimalkan Signal to Noise Ratio(SNR).

Kanal menjadi bagian penting dari sistem komunikasi nirkabel karena kualitas sinyal yang dikirim bergantung pada kanal. Kandidat frekuensi dalam $5 \mathrm{G}$ dibagi menjadi tiga band, yaitu band rendah (di bawah $1 \mathrm{GHz}$ ), band tengah (antara 1-6 GHz), dan band tinggi (di atas 6 $\mathrm{GHz}$ ). Penggunaan frekuensi tinggi 1 sampai $100 \mathrm{GHz}$ dapat menyebabkan redaman besar karena kanal yang sensitif terhadap lingkungan (suhu, tekanan udara, dedaunan, kelembapan, dII) (Medbo, dkk, 2014). Model kanal menjelaskan jumlah daya sinyal yang diterima dan Inter Symbol Interference (ISI). Oleh karena itu, kinerja sistem dapat dievaluasi berdasarkan outage performances yang berasal dari model kanal.

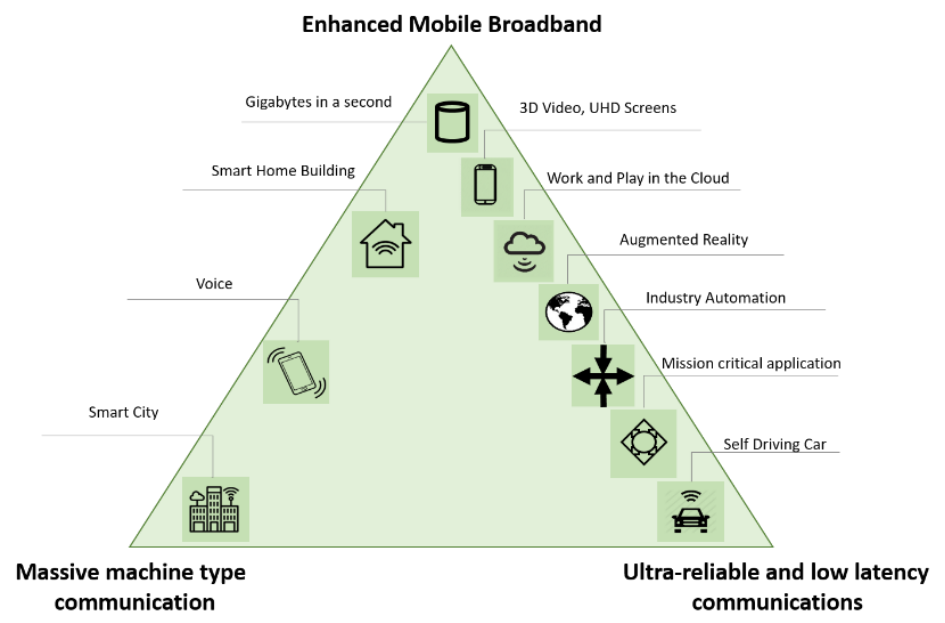

Gambar 1. Segitiga ITU-R

Beberapa negara telah melakukan penelitian terhadap model kanal $5 \mathrm{G}$ yang dipengaruhi oleh lingkungan di negaranya masing-masing, misalnya mobile and wireless communications enablers for twenty-twenty (2020) Information Society (METIS) 2020 (Raschkowski, dkk, 2015), European Telecommunications Standars Institute (ETSI) mmWave SIG (Renato Lombardi, 2018), 5G mmWave Channel Model Alliance (Gentile, dkk, 2018), Millimetre Wave Evolution for Backhaul and aAcess (MiWEBA) (Haneda, dkk, 2016), millimetre-wave based mobile radio access network for fifth-generation integrated communications (mmMagic) (Miurel Tercero, dkk, 2016), New York University (NYU) Wireless (Sun, dkk, 
2017). Penelitian-penelitian tersebut menghasilkan PDP yang berbeda-beda untuk setiap negara, karena kondisi lingkungan masing-masing negara yang berbeda. Model kanal yang berbeda direkomendasikan untuk kondisi cuaca yang berbeda- beda yang ditunjukkan pada penelitian (Hosseini, dkk, 2016) (Rappaport, 2014). Negara-negara beriklim tropis, yang secara geografis terletak di bawah garis khatulistiwa, memiliki dua musim (hujan dan kemarau). Oleh karena itu, model kanal 5G di Indonesia harus diteliti agar berbeda dengan model kanal yang sudah ada di negara lain. Model serupa telah dilakukan penelitian dengan mempertimbangkan lingkungan di Indonesia, tetapi model tersebut tidak mengamsumsikan efek dari kelembapan (Alfaroby, dkk, 2018) (Christy, dkk, 2018) (Rahman \& Anwar, 2018) (Wahyuningrum \& Anwar, 2018).

Penelitian ini mempertimbangkan model kanal $5 \mathrm{G}$ yang beroperasi pada frekuensi $3,3 \mathrm{GHz}$, karena frekuensi tersebut masih kosong di Indonesia (Admaja, 2015), dengan bandwidth $99 \mathrm{MHz}$ berdasarkan spesifikasi Orthogonal Frequency Division Multiplexing (OFDM) numerologi $\mu=1$ dalam standar $5 G$ (Zaidi, dkk, 2018) yang dapat mewakili Indonesia di bawah pengaruh kelembapan. Pengambilan data kelembapan di kota Bandung menggunakan sensor. Penelitian ini juga membandingkan PDP, outage performances, Bit-Error Rate (BER), dan Frame Error Rate (FER) untuk memastikan validitas perhitungan.

\section{METODE}

Penelitian ini melakukan pengujian sistem OFDM dari 5G NR dengan menggunakan numerologi $\mu=1$ pada kanal $5 \mathrm{G}$ Indonesia. Penelitian ini membahas model kanal $5 \mathrm{G}$ yang beroperasi pada frekuensi 3,3 GHz dengan bandwidth $99 \mathrm{MHz}$ berdasarkan spesifikasi OFDM numerologi $\mu=1$ dengan mempertimbangkan pengaruh kelembapan.

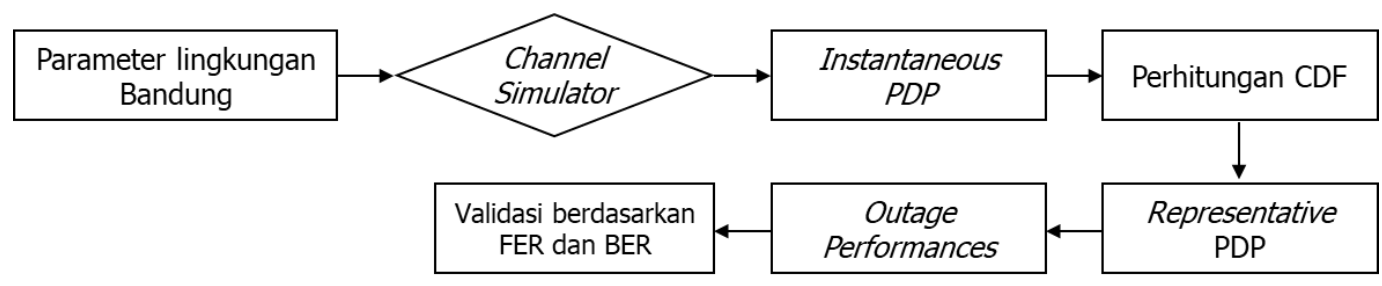

Gambar 2. Blok Diagram Kanal 5G dengan Pengaruh Kelembapan

Gambar 2 menunjukkan pemodelan kanal 5G menggunakan parameter lingkungan kota Bandung yang dianggap dapat merepresentasikan kondisi alam di Indonesia sebagai batas cakupan dalam penelitian ini. Evaluasi dari performansi pada model kanal $5 \mathrm{G}$ dimulai dengan menentukan parameter-parameter lingkungan kota Bandung, antara lain kelembapan maksimum, kelembapan minimum, rata-rata tekanan udara, dan suhu rata-rata yang diperoleh dari data pengukuran langsung lingkungan selama tiga bulan di kota Bandung menggunakan mikrokontroler Arduino dan sensor BME280. Kemudian, parameter lingkungan yang telah diperoleh menjadi inputpada simulator pemodelan kanal 5G. Simulator menghasilkan keluaran berupa instantaneous PDP yang berisi daya dan delay untuk setiap path yang mewakili kanal berdasarkan OFDM numerologi $\mu=1$. Instantaneous PDP adalah nilai PDP sesaat yang masih bervariasi terhadap waktu. Kemudian, delay dari setiap PDP akan dibulatkan dengan rentang pembulatan yang berbeda-beda menurut teorema Nyquist dengan mempertimbangkan bandwidth yang digunakan untuk OFDM numerologi $\mu=1$. Penentuan representative PDP dilakukan dengan menghitung persentil ke-90 dari Cumulative dDstribution Function (CDF) setiap path. Nilai representative PDP akan diberikan threshold sebesar $-140 \mathrm{~dB}$ sehingga nilai 
di bawah threshold tersebut akan dianggap sebagai noise. Pemberian threshold tersebut berdasarkan asumsi bahwa perangkat $5 \mathrm{G}$ di Indonesia pada masa mendatang memiliki sensitivitas perangkat sekitar $-140 \mathrm{~dB}$. Langkah terakhir dalam proses pengolahan PDP adalah melakukan normalisasi untuk setiap representative PDP yang diperoleh setelah melewati thresholding. Langkah selanjutnya adalah perhitungan outage performances yang diperoleh dari perhitungan outage probability dari kanal ketika $\mathrm{R}>\mathrm{C}$ (Molisch, 2011), maka kesalahan tidak dapat dihindari dari penggunaan teknik koding dalam sistem. Outage probability dalam coding rate $R$ dinyatakan pada Persamaan (1).

$$
P_{\text {outage }}(R)=P_{r}\left(R>\sum_{n=1}^{N} \log _{2}\left(1+\left|\psi_{n}\right|^{2} \cdot \frac{S}{N_{n}}\right)\right),
$$

Dengan $S$ adalah sinyal data yang ditransmisikan dan $N_{n}$ adalah noise yang bervariasi pada kanal multipath fading. Setelah mendapatkan outage performances maka dapat dilakukan validasi menggunakan performansi dari FER berdasarkan modulasi Complex-Binary Phase Shift Keying (C-BPSK). FER dinyatakan pada Persamaan (2).

$$
F E R=\frac{F_{e}}{F_{t}},
$$

Dengan $F_{e}$ adalah jumlah frame yang error dan $F_{t}$ adalah jumlah frame yang ditransmisikan. Frame dianggap error ketika terdapat setidaknya satu bit dalam frame tersebut error.

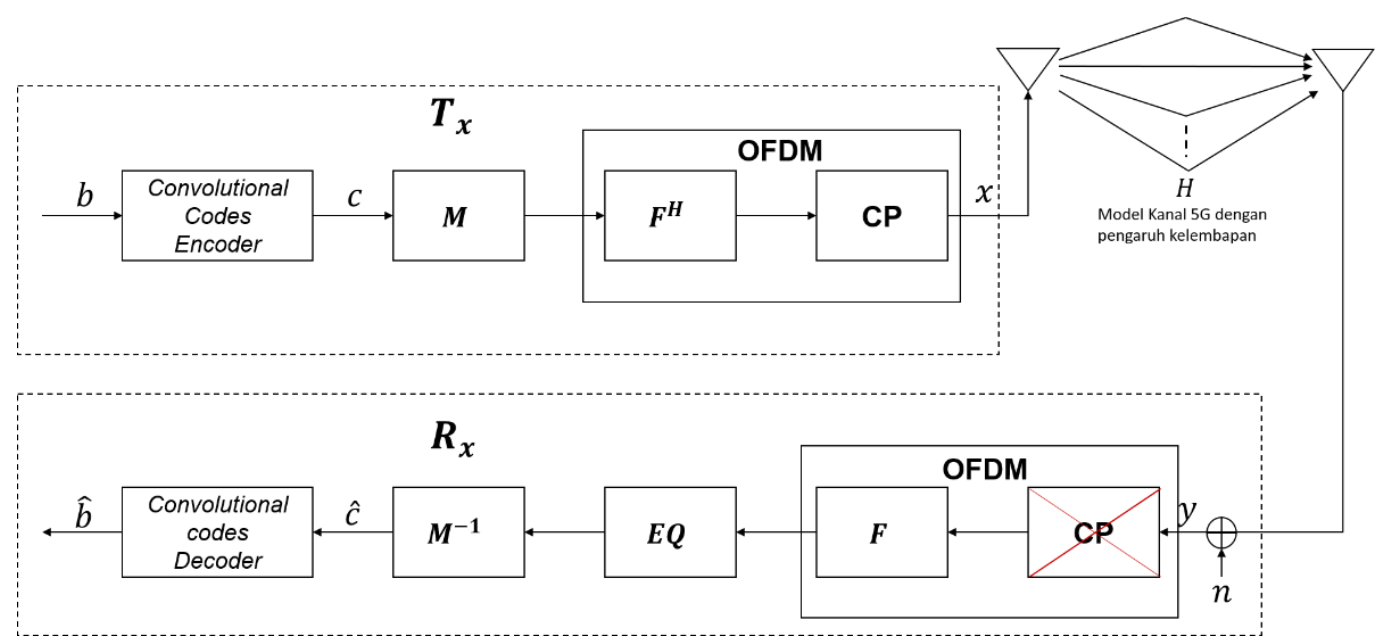

\section{Gambar 3. Struktur Blok Transmitter dan Receiver dari CP-OFDM untuk Validasi Performansi 5G NR}

Gambar 3 menunjukkan struktur CP-OFDM untuk memvalidasi hasil outage performances setiap OFDM numerologi pada kanal $5 \mathrm{G}$ menggunakan convolutional codes. Bit informasi $b$ dibangkitkan pada sisi $T_{x}$ secara acak dengan probabilitas kemunculan bit 0 dan 1 yang sama. Setelah dibangkitkan, informasi $c$ akan dipetakan dan dimodulasi pada modulator $M$ untuk menghasilkan simbol yang berisi bit-bit informasi, modulasi yang digunakan adalah C-BPSK. Simbol keluaran dari modulator kemudian ditransformasikan menggunakan IFFT $F^{H}$ dengan panjang blok sebesar 128 untuk mengubah simbol dari domain frekuensi menjadi simbol dalam domain waktu. Blok $C P$ berfungsi untuk menambahkan sejumlah bagian akhir simbol keluaran IFFT ke depan simbolnya sehingga membentuk simbol baru $x$ dengan memperhatikan ketentuan jumlah CP. Panjang CP $Q$ yang ditambahkan dalam sistem OFDM $\mu=1$ yang dinyatakan pada Persamaan (3).

$$
Q=\frac{T_{c p}}{T_{O F D M}} \cdot N_{F F T},
$$


Dengan $T_{c p}$ adalah durasi CP $\mu=1, T_{O F D M}$ adalah durasi simbol OFDM $\mu=1$, dan $N_{F F T}$ adalah ukuran FFT. CP menjadi salah satu parameter yang penting pada OFDM karena mampu menghilangkan Inter-Symbol Interference (ISI) selama panjang CP lebih besar atau sama dengan jumlah path dalam kanal. Simbol-simbol $x$ tersebut kemudian ditransmisikan melalui kanal 5G dengan pengaruh kelembapan. Simbol yang diterima pada sisi receiver akan terkena noisen sebelum simbol $y$ masuk ke blok penghapusan CP. CP dalam simbol $y$ akan dihapuskan dalam blok CP Removal dan menjadi simbol baru. Setelah itu, simbol akan ditransformasikan kembali menggunakan FFT $F$ untuk menghasilkan. Setelah itu, simbol didemodulasi menggunakan demodulator $M^{-1}$. Langkah terakhir adalah proses decoder untuk mengembalikan nilai $\hat{c}$ ke dalam bentuk bit-bit informasi $\hat{b}$ dan menentukan apakah bit-bit yang diterima tersebut adalah bit 0 atau 1 yang diharapkan sesuai dengan bit informasi yang ditransmisikan. Bit informasi yang tidak sesuai dapat dihitung dan dianalisis Bit Error Rate (BER) berdasarkan pada sistem CP-OFDM yang dinyatakan pada Persamaan (4).

$$
B E R=\frac{B_{e}}{B_{t}}
$$

Dengan $B_{e}$ adalah jumlah bit yang error dan $B_{t}$ adalah jumlah bit yang ditransmisikan.

\section{HASIL DAN PEMBAHASAN}

\subsection{Model Kanal 5G}

Model kanal 5G Indonesia diperoleh berdasarkan representative PDP untuk OFDM numerologi $\mu=1$ yang dihitung dari 2000 instataneous PDP yang dibangkitkan dari simulator dengan mengambil nilai persentil ke-90 dari CDF dan batas minimum daya PDP yang diambil sebesar $-140 \mathrm{~dB}$ sebelum representative PDP akan dinormalisasi. Pengambilan nilai persentil ke-90 tersebut dilandaskan pada distribusi PDP yang cenderung bernilai kecil sehingga penentuan CDF ini diharapkan dapat memberikan nilai PDP yang paling mewaliki untuk setiap path. Daya dari path yang berada di bawah $-140 \mathrm{~dB}$ dianggap sebagai noise. Proses normalisasi dilakukan pada PDP yang memiliki daya terkuat untuk setiap path. Daya representative PDP dari kanal 5G Indonesia mengalami penurunan secara eksponensial yang menandakan bahwa diversity akan dicapai pada nilai SNR yang tinggi. Berdasarkan data lingkungan kota Bandung yang diambil dari pengukuran langsung menggunakan sensor selama tiga bulan.

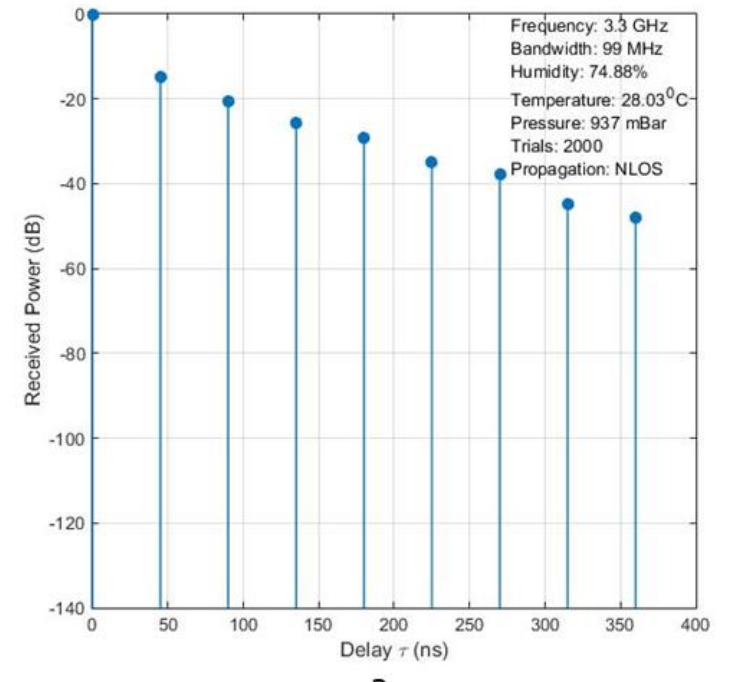

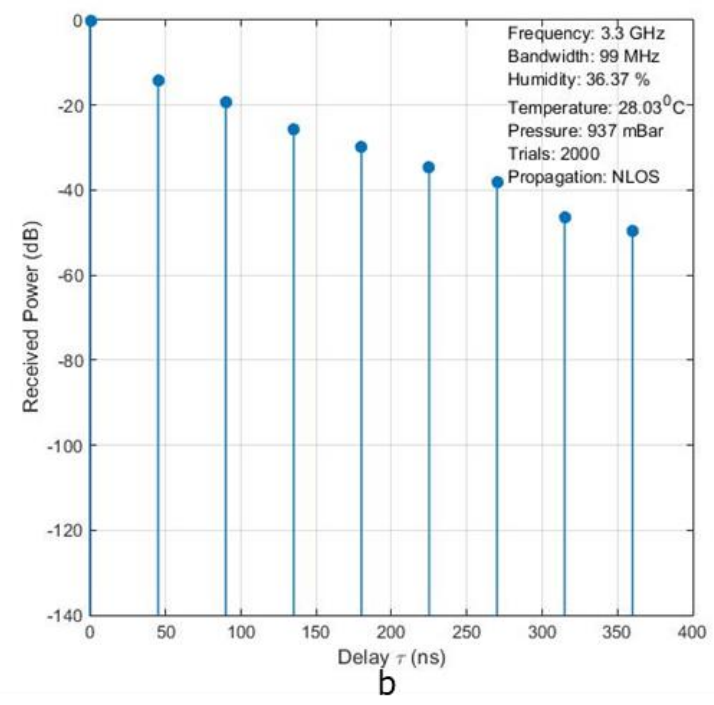

Gambar 4. PDP Representatif dengan Pengaruh: a. Kelembapan Maksimum, b. Kelembapan Minimum 
Karakterirstik lingkungan dengan kelembapan minimum sebesar 36,37\%, kelembapan maksimum sebesar $74,88 \%$, kelembapan rata-rata sebesar $53,4 \%$, suhu rata-rata sebesar $28,03^{\circ} \mathrm{C}$, dan tekanan udara rata-rata sebesar 937 mbar. Parameter frekuensi sebesar 3,3 $\mathrm{GHz}$, dan parameter bandwidth sebesar $99 \mathrm{MHz}$ menjadi parameter input pada simulator yang digunakan untuk menghasilkan 2000 instataneous PDP.

Penelitian ini menggunakan panjang $\mathrm{CP}$ untuk OFDM $\mu=1$, yaitu $\mathrm{Q} \approx 9$ yang diperoleh dari Persamaan (3). Durasi CP sebesar 2,3 $\mu$ s, durasi simbol OFDM sebesar 33,3 $\mu$ s, dan ukuran FFT sebesar 128. Simulasi penelitian ini memperoleh karakteristik dari model kanal 5G, yaitu sebanyak sembilan path untuk kelembapan maksimum $\left(H_{\max }\right)$ ditunjukkan pada Gambar 4.a dan kelembapan minimum $\left(\mathrm{H}_{\min }\right)$ ditunjukkan pada Gambar 4.b. Informasi mengenai nilai daya path yang pada kelembapan maksimal $\left(H_{\max }\right)$ dan kelembapan minimal $\left(\mathrm{H}_{\min }\right)$ yang ditunjukkan pada Tabel 1.

Tabel 1. Daya PDP dengan Pengaruh Kelembapan Maksimum dan Minimum

\begin{tabular}{|c|c|c|c|}
\hline Path & Daya $\boldsymbol{H}_{\text {max }}(\mathbf{d B})$ & Daya $\mathbf{H}_{\min }(\mathbf{d B})$ & Delay (ns) \\
\hline 1 & 0 & 0 & 0 \\
\hline 2 & $-14,875$ & $-14,235$ & 45 \\
\hline 3 & $-20,689$ & $-19,303$ & 90 \\
\hline 4 & $-25,541$ & $-25,664$ & 135 \\
\hline 5 & $-29,241$ & $-29,913$ & 180 \\
\hline 6 & $-34,963$ & $-34,664$ & 225 \\
\hline 7 & $-37,767$ & $-38,109$ & 270 \\
\hline 8 & $-44,787$ & $-46,484$ & 315 \\
\hline 9 & $-49,700$ & $-47,943$ & 360 \\
\hline
\end{tabular}

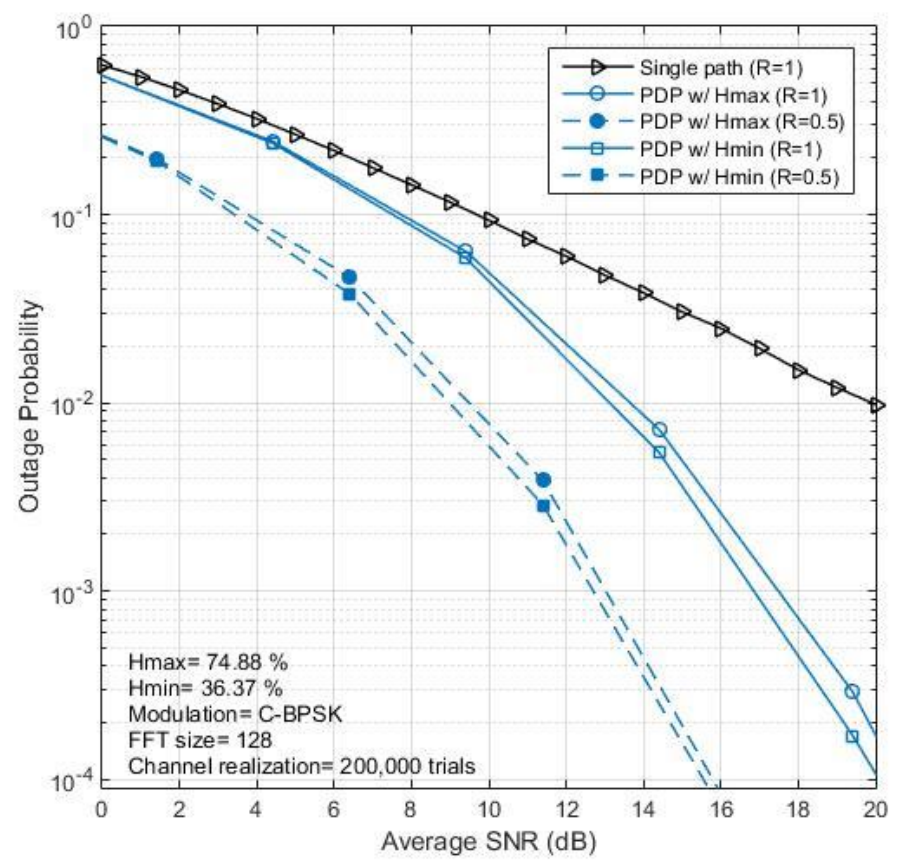

Gambar 5. Outage Performances Model Kanal 5G dengan Pengaruh Kelembapan 


\subsection{Analisis Outage Performances pada Model Kanal 5G}

Penelitian ini melakukan analisis terhadap outage performances dari kanal 5G untuk OFDM numerologi $\mu=1$ dengan mengevaluasi CDF dari kapasitas kanal $C$ yang dihitung pada channel coding rate $R=1$ (uncoded) dan $R=\frac{1}{2}$ (convolutional codes) dengan modulasi C-BPSK yang memiliki indeks modulasi $m=1$. Gambar 5 menunjukkan lima kurva outage performances dari model kanal $5 \mathrm{G}$ dengan 9 path untuk channel coding $R=\left\{\frac{1}{2}, 1\right\}$. Lima kurva outage performances memiliki gradien sama yang mengindikasikan bahwa kelima kurva tersebut memiliki diversity order serbesar $10^{-3}$ sistem 5G dengan SNR $\gamma=0-25 \mathrm{~dB}$. Gambar 5 menunjukkan outage performances dengan pengaruh kelembapan pada $\mathrm{R}=1$ untuk $H_{\max }$ sebesar SNR $\gamma=17,7 \mathrm{~dB}$ dan untuk $\mathrm{H}_{\min }$ sebesar SNR $\gamma=17 \mathrm{~dB}$. Outage performances pada $\mathrm{R}=1 / 2$ untuk $H_{\max }$ sebesar SNR $\gamma=13 \mathrm{~dB}$ dan untuk $\mathrm{H}_{\min }$ sebesar SNR $\gamma=12,7 \mathrm{~dB}$. Hasil penelitian ini menunjukkan outage performances model kanal 5G dengan kelembapan maksimal $H_{\max }$ dan kelembapan minimal $H_{\min }$ memiliki kinerja yang lebih baik dibandingkan dengan singlepath karena adanya pengaruh dari kanal multipath fading.

\subsection{Pengujian Frame Error Rate (FER)}

Penelitian ini melakukan validasi terhadap outage performances dari model kanal $5 \mathrm{G}$ untuk OFDM numerologi $\mu=1$ dengan pengujian FER. Pengujian FER tersebut menggunakan coding rate $R=1$ untuk uncoded, $R=1 / 2$ untuk convolutional codes, dan menggunakan modulasi C-BPSK. Outage performances kanal 5G dapat divalidasi menggunakan FER dengan syarat kurva outage performances memiliki gradien yang sama dengan kurva FER. Pada penelitian ini performansi FER dari model kanal $5 \mathrm{G}$ dihitung menggunakan parameter ukuran FFT sebesar 128 , jumlah frame sebanyak 200.000, dan panjang CP $Q \approx 9$ untuk OFDM $\mu=1$.

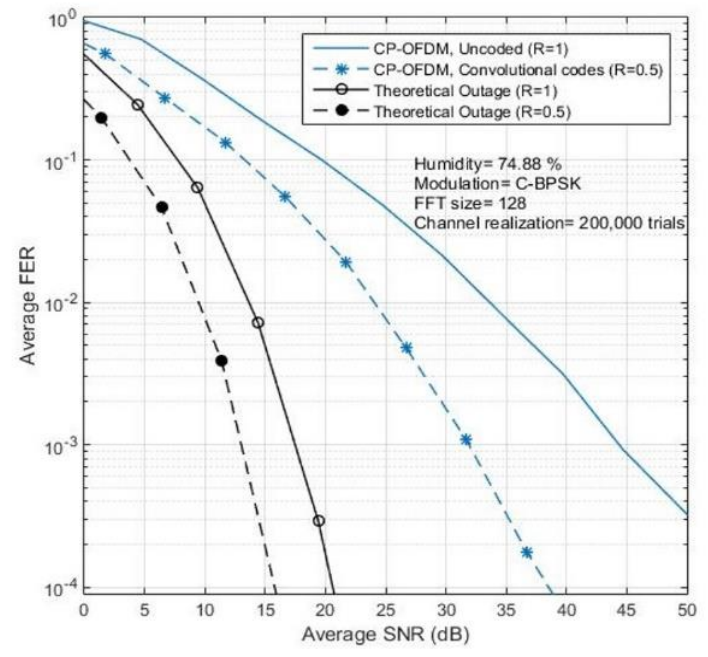

a

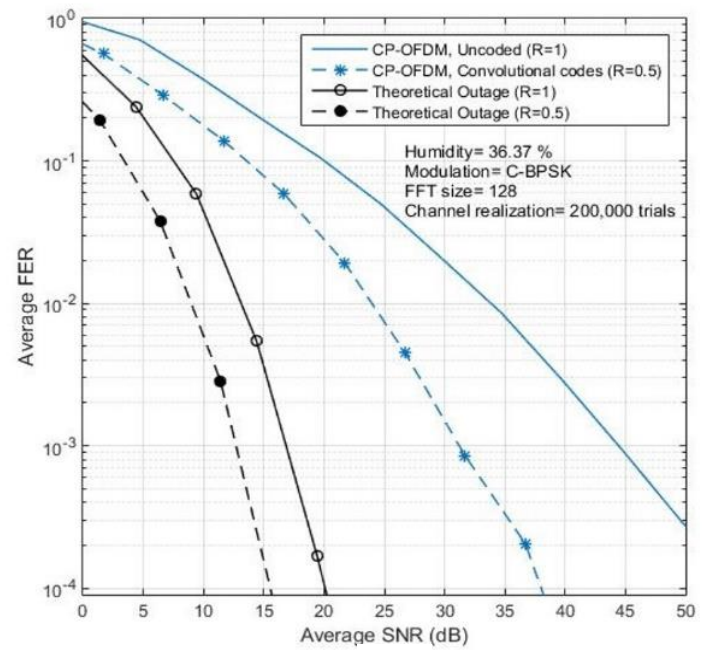

b

Gambar 6. FER Model Kanal 5G dengan Pengaruh Kelembapan:

(a) Maksimum dan (b) Minimum

Gambar 6 menunjukkan perbandingan channel coding rate $R=\{1 / 2,1\}$ dengan teori outage performances dengan $R=\{1 / 2,1\}$ pada kelembapan maksimal $\left(H_{\max }\right)$ dan kelembapan minimum $\left(H_{\min }\right)$. Tabel 2 menunjukkan hasil FER dengan pengaruh kelembapan minimum $\left(\mathrm{H}_{\min }\right)$ membutuhkan SNR yang lebih kecil dibandingkan kelembapan maksimum $\left(\mathrm{H}_{\max }\right)$ karena memiliki gap sebesar 0,2 dB pada uncoded dan gap sebesar $1 \mathrm{~dB}$ pada convolutional codes. Penggunaan convolutional codes pada pengujian FER berhasil menghemat SNR sebesar $12,5 \mathrm{~dB}$ pada $\mathrm{H}_{\max }$ dan $13,3 \mathrm{~dB}$ pada $\mathrm{H}_{\min }$ dibandingkan dengan uncoded. 
Model Kanal 5G dengan Pengaruh Kelembapan pada Frekuensi 3,3 GHz dan Bandwidth $99 \mathrm{MHz}$ Berbasis Convolutional Codes

Tabel 2. Nilai SNR pada FER Model Kanal 5G dengan Convolutional Codes dan Uncoded

\begin{tabular}{|c|c|c|c|c|}
\hline \multirow{2}{*}{ FER } & \multicolumn{2}{|c|}{$H_{\text {max }}$} & \multicolumn{2}{c|}{$\mathrm{H}_{\text {min }}$} \\
\cline { 2 - 5 } & $\begin{array}{c}\text { SNR } \\
\text { convolutional } \\
\text { codes (dB) }\end{array}$ & $\begin{array}{c}\text { SNR uncoded } \\
\text { (dB) }\end{array}$ & $\begin{array}{c}\text { SNR } \\
\text { convolutional } \\
\text { codes (dB) }\end{array}$ & $\begin{array}{c}\text { SNR uncoded } \\
\text { (dB) }\end{array}$ \\
\hline $10^{-3}$ & 32 & 44,5 & 31 & 44,3 \\
\hline
\end{tabular}

\subsection{Pengujian Bit Error Rate (BER)}

Penelitian ini menampilkan kinerja dari BER dengan sistem CP-OFDM yang ditunjukkan pada Gambar 7 untuk model kanal 5G dengan pengaruh kelembapan maksimum dan minimum.

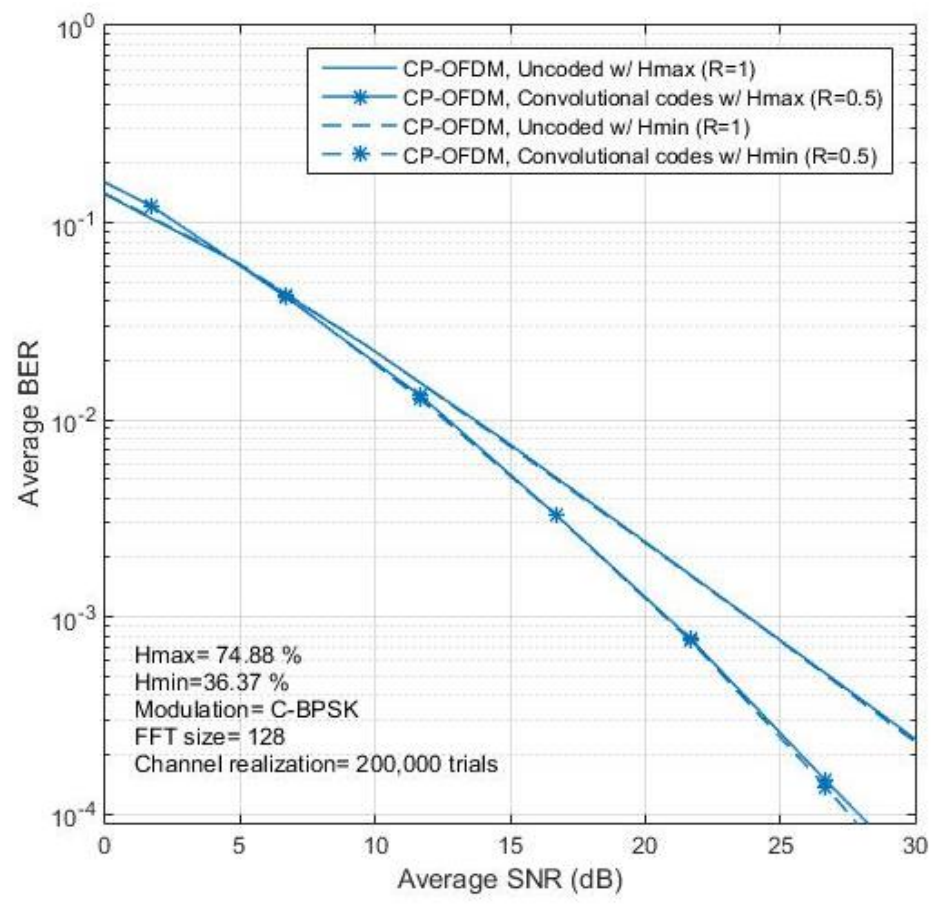

Gambar 7. BER Model Kanal 5G dengan Pengaruh Kelembapan

Penelitian ini membandingkan hasil simulasi kinerja BER dengan convolutional codes dan tanpa coding (uncoded). Penelitan ini menemukan bahwa kinerja BER dari convolutional codes memiliki kinerja yang lebih baik dibandingkan dengan uncoded. BER sebesar $10^{-3}$ pada convolutional codes memerlukan SNR sebesar $21 \mathrm{~dB}$ dan uncoded memerlukan SNR sebesar $24 \mathrm{~dB}$, maka daya yang dibutuhkan dengan menggunakan convolutional codes lebih kecil dibandingkan dengan uncoded.

\section{KESIMPULAN}

Penelitian ini menunjukkan PDP representatif dengan pengaruh kelembapan maksimum $\left(H_{\max }\right)$ dan minimun $\left(H_{\min }\right)$ masing-masing memiliki sebanyak 9 path. Outage performances dengan pengaruh kelembapan maksimum memiliki gap Signal to Noise Ratio (SNR) sebesar 0,3 dB, lebih besar dibandingkan dengan kelembapan minimum. Sehingga, model kanal 5G dengan pengaruh kelembapan maksimum memiliki outage performances yang lebih buruk dibandingkan dengan kelembapan minimum. Penelitian ini juga menemukan bahwa 
convolutional codes dapat menghemat daya sebesar $3 \mathrm{~dB}$ dibandingkan tanpa channel codes (uncoded) yang digunakan untuk memvalidasi outage performances. Keluaran dari penelitian ini diharapkan dapat menjadi referensi pengembangan komunikasi nirkabel $5 \mathrm{G}$ di Indonesia.

\section{UCAPAN TERIMA KASIH}

Penulis mengucapkan terima kasih kepada bapak Dr. Eng Khoirul Anwar yang telah memberikan ide, masukan-masukan, dan bimbingan yang sangat membantu penulis dalam menyelesaikan penelitian ini. Terima kasih juga kepada Lembaga Penelitian dan Pengabdian Masyarakat (LPPM) Institut Teknologi Telkom Purwokerto yang telah mendukung penelitian ini.

\section{DAFTAR RUJUKAN}

Admaja, A. F. S. (2015). Kajian Awal 5G Indonesia (5G Indonesia Early Preview). Buletin Pos dan Telekomunikasi, 13(2), 97. https://doi.org/10.17933/bpostel.2015.130201

Alfaroby, E. M., Adriansyah, N. M., \& Anwar, K. (2018). Study on channel model for Indonesia 5G networks. 2018 International Conference on Signals and Systems (ICSigSys), (pp. 125-130). https://doi.org/10.1109/ICSIGSYS.2018.8372650

Christy, E., Astuti, R. P., \& Anwar, K. (2018). Telkom University 5G Channel Models Under Foliage Effect and Their Performance Evaluations. 2018 International Conference on ICT for Rural Development (IC-ICTRuDev), (pp. 29-34). https://doi.org/10.1109/ICICTR.2018.8706848

Gentile, C., Papazian, P. B., Golmie, N., Remley, K. A., Vouras, P., Senic, J., Wang, J., Caudill, D., Lai, C., Sun, R., \& Chuang, J. (2018). Millimeter-Wave Channel Measurement and Modeling: A NIST Perspective. IEEE Communications Magazine, 56(12), 30-37. https://doi.org/10.1109/MCOM.2018.1800222

Haneda, K., Lei Tian, Asplund, H., Jian Li, Yi Wang, Steer, D., Li, C., Balercia, T., Sunguk Lee, YoungSuk Kim, Ghosh, A., Thomas, T., Nakamurai, T., Kakishima, Y., Imai, T., Papadopoulas, H., Rappaport, T. S., MacCartney, G. R., Samimi, M. K., ... Ghosh, A. (2016). Indoor 5G 3GPP-like channel models for office and shopping mall environments. 2016 IEEE International Conference on Communications Workshops (ICC), (pp. 694-699). https://doi.org/10.1109/ICCW.2016.7503868

Hosseini, S. A., Zarepour, E., Hassan, M., \& Chou, C. T. (2016). Analyzing diurnal variations of millimeter wave channels. 2016 IEEE Conference on Computer Communications Workshops (INFOCOM WKSHPS), (pp. 377-382). https://doi.org/10.1109/INFCOMW.2016.7562105 
Medbo, J., Börner, K., Haneda, K., Hovinen, V., Imai, T., Järvelainen, J., Jämsä, T., Karttunen, A., Kusume, K., Kyröläinen, J., Kyösti, P., Meinilä, J., Nurmela, V., Raschkowski, L., Roivainen, A., \& Ylitalo, J. (2014). Channel Modelling for the Fifth Generation Mobile Communications. 5.

Miurel Tercero, J. W., Peter von Wrycza, A. A., Maria Fresia, V. F., \& Javier Lorca, T. S. (2016). $5 \mathrm{G}$ system: The mmMAGIC project perspective on Use cases and Challenges between 6-100 GHz. IEEE Wireless Communications and Networking Conference, 6. https://doi.org/10.1109/WCNC.2016.7564670

Molisch, A. F. (2011). Wireless communications (2nd ed). Wiley : IEEE.

Rahman, M. N., \& Anwar, K. (2018). Outage Performances of $5 G$ Channel Model Considering Temperature Effects at $28 \mathrm{GHz} .2$.

Rappaport, T. S. (2014). $73 \mathrm{GHz}$ millimeter wave propagation measurements for outdoor urban mobile and backhaul communications in New York City. 2014 IEEE International Conference on Communications (ICC), (pp. 4862-4867). https://doi.org/10.1109/ICC.2014.6884090

Raschkowski, L., Kyösti, P., Kusume, K., \& Jämsä, T. (2015). METIS Channel Models.

Renato Lombardi. (2018). Microwave and Millimetre-wave for $5 G$ Transport (06921 Sophia Antipolis CEDEX, France). ETSI.

Sun, S., MacCartney Jr., G. R., \& Rappaport, T. S. (2017). A Novel Millimeter-Wave Channel Simulator and Applications for 5G Wireless Communications. ArXiv:1703.08232 [CS, Math]. http://arxiv.org/abs/1703.08232

Wahyuningrum, R. D., \& Anwar, K. (2018). Outage Performance of 5 G Channel Model Considering Humidity Effects. Symposium of Future Telecommunication and Technologies, 2.

Zaidi, A. A., Baldemair, R., Moles-Cases, V., He, N., Werner, K., \& Cedergren, A. (2018). OFDM Numerology Design for $5 \mathrm{G}$ New Radio to Support IoT, eMBB, and MBSFN. IEEE Communications Standards Magazine, 2(2), 78-83. https://doi.org/10.1109/MCOMSTD.2018.1700021 